\title{
Group I introns and associated homing endonuclease genes reveals a clinal structure for Porphyra spiralis var. amplifolia (Bangiales, Rhodophyta) along the Eastern coast of South America Daniela Milstein ${ }^{1}$, Mariana C Oliveira*1, Felipe M Martins ${ }^{2}$ and Sergio R Matioli ${ }^{2}$
}

\author{
Address: ${ }^{1}$ Departamento de Botânica, Instituto de Biociências, Universidade de São Paulo, Rua do Matão, 277, cep 05508-900, Brazil and \\ ${ }^{2}$ Departamento de Genética e Biologia Evolutiva, Instituto de Biociências, Universidade de São Paulo, Rua do Matão, 277, cep 05508-900, Brazil \\ Email: Daniela Milstein - danielamilstein@hotmail.com; Mariana C Oliveira* - mcdolive@usp.br; \\ Felipe M Martins - felipemartins@hotmail.com; Sergio R Matioli - srmatiol@ib.usp.br \\ * Corresponding author
}

Published: 7 November 2008

BMC Evolutionary Biology 2008, 8:308 doi:10.1/86/147/-2/48-8-308

This article is available from: http://www.biomedcentral.com/I47|-2/48/8/308

(C) 2008 Milstein et al; licensee BioMed Central Ltd.

This is an Open Access article distributed under the terms of the Creative Commons Attribution License (http://creativecommons.org/licenses/by/2.0), which permits unrestricted use, distribution, and reproduction in any medium, provided the original work is properly cited.

\begin{abstract}
Background: Group I introns are found in the nuclear small subunit ribosomal RNA gene (SSU rDNA) of some species of the genus Porphyra (Bangiales, Rhodophyta). Size polymorphisms in group I introns has been interpreted as the result of the degeneration of homing endonuclease genes (HEG) inserted in peripheral loops of intron paired elements. In this study, intron size polymorphisms were characterized for different Porphyra spiralis var. amplifolia (PSA) populations on the Southern Brazilian coast, and were used to infer genetic relationships and genetic structure of these PSA populations, in addition to cox2-3 and rbcL-S regions. Introns of different sizes were tested qualitatively for in vitro self-splicing.
\end{abstract}

Results: Five intron size polymorphisms within 17 haplotypes were obtained from 80 individuals representing eight localities along the distribution of PSA in the Eastern coast of South America. In order to infer genetic structure and genetic relationships of PSA, these polymorphisms and haplotypes were used as markers for pairwise Fst analyses, Mantel's test and median joining network. The five cox2-3 haplotypes and the unique rbcL-S haplotype were used as markers for summary statistics, neutrality tests Tajima's $D$ and Fu's $F_{s}$ and for median joining network analyses. An event of demographic expansion from a population with low effective number, followed by a pattern of isolation by distance was obtained for PSA populations with the three analyses. In vitro experiments have shown that introns of different lengths were able to selfsplice from pre-RNA transcripts.

Conclusion: The findings indicated that degenerated HEGs are reminiscent of the presence of a fulllength and functional HEG, once fixed for PSA populations. The cline of HEG degeneration determined the pattern of isolation by distance. Analyses with the other markers indicated an event of demographic expansion from a population with low effective number. The different degrees of degeneration of the HEG do not refrain intron self-splicing. To our knowledge, this was the first study to address intraspecific evolutionary history of a nuclear group I intron; to use nuclear, mitochondrial and chloroplast DNA for population level analyses of Porphyra; and intron size polymorphism as a marker for population genetics. 


\section{Background}

Group I introns belong to a family of RNAs with catalytic activities. These ribozymes are mobile elements inserted within coding sequences of nuclear rDNA, chloroplast and mitochondrial genomes of some eukaryotes; and less frequently within coding sequences of eubacteria, phages and viruses. Group I introns catalyze their own excision (self-splicing) from pre-mRNA when mature RNA is being processed. The exact site of intron excision and the perfect reestablishment of the interrupted message are defined by specific interactions between intron and exons, determined by a conserved secondary structure. Group I introns fold on a structure, forming 10 conserved paired elements (P1-P10) with a conserved catalytic core [reviewed in [1]].

Size polymorphisms in group I introns have been described [2-5] and are occasionally generated by the insertion of a mobile element such as homing endonuclease genes (HEG) in peripheral loops of intron paired elements P1, P2, P6, P8 and P9 [4,6]. Homing endonuclease genes encode for site specific homing endonucleases (HEs), which in genetic crosses between an HEG containing intron allele and an intronless allele, recognize the intron insertion site and catalyze a double strand break. The intronless allele is then repaired using the HEG containing intron allele as a template. This mechanism of intron mobility is known as homing [6]. Homing endonucleases are classified in five different families according to conserved protein motifs and functional and structural properties: LAGLIDADG; GIY-YIG; H-N-H; His-Cys box [6-8]; and the recently described PD-(D/E)-XK motif [9]. His-Cys box motifs are identified in HE exclusively associated to nuclear group I introns [10]. Homing endonucleases were described for fungi, protists, bacteria and viruses, but with unknown function for the hosts [6].

Descriptions of group I introns in Rhodophyta are limited to a few genera [11-13], although it is commonly reported for the genera Porphyra and Bangia (Bangiales, Rhodophyta) [13-15]. A survey for group I introns presence in the order (Bangiales) described by Müller et al. [5], indicated that this order is a particularly rich in these introns. The use of introns as molecular markers at the intra-specific level is very limited $[2,16,17]$. Usually in Rhodophyta, analyses at the intra-specific level are addressed with molecular markers such as the nuclear rDNA internal transcribed spacer (ITS) 1 and 2 [18,19]; the plastidial spacer between the ribulose-1, 5-bisphosphate carboxylase-oxygenase large subunit $(r b c \mathrm{~L})$ and the small subunit $(r b c S)$ genes $(r b c L-S)[20,21]$, and the mitochondrial spacer between the cytochrome oxidase subunit 2 and subunit 3 genes (cox2-3) [19,21-23].
In a previous work, Oliveira and Ragan [2] characterized introns of different sizes inserted in the nuclear small subunit rRNA gene (SSU rDNA) close to the 3 ' end (intron S1506) of three Porphyra spiralis var. amplifolia (PSA) individuals collected at different sites on the Southern Brazilian coast. Open reading frames (ORFs) with His-Cys Box motifs were described inserted in the P1 paired element, confined within the conserved pair $U^{*} G$, located in the SSU rDNA exon and in the intron respectively in the complementary strand. This region is known as P1-extension [4]. These findings prompted us to: 1) characterize introns size polymorphisms at different PSA populations on the Eastern coast of South America; 2) Infer genetic relationships and population structure of PSA populations using introns in addition to $r b c \mathrm{~L}-\mathrm{S}$ and $\operatorname{cox} 2-3$ regions as genetic markers; and 3) Verify if the different polymorphisms in peripheral loop of intron P1 paired element affected qualitatively introns excision, through an in vitro self-splicing assay.

\section{Methods}

\section{DNA extraction, PCR amplification and sequencing}

Population samples of Porphyra spiralis var. amplifolia were collected at eight different sites in the Southern Brazilian shore (Table 1, Figure 1). A minimum of 10 individuals were obtained from each site. Gametophyte blades were identified based on morphological description [24], and did not present any meaningful morphological variation among and within populations. Samples were screened for epiphytes using a stereomicroscope, and stored individually in silica gel. Each individual was ground in liquid nitrogen and total genomic DNA was extracted using the "DNeasy Plant Mini Kit" (Qiagen, Santa Clarita, CA), according to manufacturer's specifications. Voucher specimens are deposited at University of São Paulo herbarium (SPF, Table 1).

Total DNA was extracted from 10 individuals for each of the eight geographic locations. Primers 1400F and 18S3' were used to amplify part of the $3^{\prime}$ end of the first SSU rDNA exon + intron + the 5' end of the second SSU rDNA exon; as a positive control for intron presence in the multiple SSU rDNA copies [25] primers 1400F and iR2 were used to amplify HEG-containing ORF, including the flanking 213 bp of the SSU rDNA 5'exon and 175 bp of the intron. Primers COX $2 \mathrm{~F}$ and COX $3 \mathrm{R}$ were used to amplify the $3^{\prime}$ end of $\operatorname{cox} 2$ gene + spacer $+5^{\prime}$ end of $\operatorname{cox} 3$ gene; and primers F993 and RBCS3'R were used to amplify the $3^{\prime}$ end of $r b c \mathrm{~L}$ gene + spacer $+5^{\prime}$ end of $r b c S$ gene.

PCR amplification conditions for a total volume of $50 \mu \mathrm{L}$ were: $1 \times$ PCR buffer, $1.5 \mathrm{mM} \mathrm{MgCl}_{2}, 0.2 \mathrm{mM}$ each dNTP, $0.2 \mu \mathrm{M}$ each primer, $20 \mathrm{ng}$ of genomic DNA and $1.25 \mathrm{U}$ of Taq DNA polymerase (Promega Corporation, Madison, 
Table I: Porphyra spiralis var. amplifolia (PSA) collection information.

\begin{tabular}{|c|c|c|c|c|c|}
\hline Population & Collection location & Latitude (S)/Longitude (W) & Collector & Date & Voucher \\
\hline PSA-V & Vermelha do Norte, Ubatuba, SP & $23^{\circ} 25^{\prime} 16.96^{\prime \prime} / 45^{\circ} 02^{\prime} 21.75^{\prime \prime}$ & $\mathrm{MCO}$ & Aug 1998 & SPF 56191 \\
\hline PSA-B' & Fortaleza, Ubatuba, SP & $23^{\circ} 3 I^{\prime} 55.48^{\prime \prime} / 45^{\circ} 09^{\prime} 42.28^{\prime \prime}$ & $\mathrm{MCO}$ & Oct 1990 & $*$ \\
\hline PSA-D' & Cebimar, São Sebastião, SP & $23^{\circ} 49^{\prime} 41.70^{\prime \prime} / 45^{\circ} 25^{\prime} 20.87^{\prime \prime}$ & $\mathrm{MCO}$ & Oct 1990 & $*$ \\
\hline PSA-C & Baleia, São Sebastião, SP & $23^{\circ} 46^{\prime} 49.78^{\prime \prime} / 45^{\circ} 39^{\prime} 51.53^{\prime \prime}$ & DM & Aug 2002 & SPF 56183 \\
\hline PSA-G & Tijucopava, Guarujá, SP & $23^{\circ} 54^{\prime} 54.72^{\prime \prime} / 46^{\circ} 10^{\prime} 03.2 I^{\prime \prime}$ & DM & Jul 2002 & SPF 56185 \\
\hline PSA-S & Itaipu, Santos, SP & $24^{\circ} 0 I^{\prime} \mid 2.02^{\prime \prime} / 46^{\circ} 23^{\prime} 57.57^{\prime \prime}$ & ECO & Aug 1997 & SPF 56189 \\
\hline PSA-T & Tombo, Guarujá, SP & $24^{\circ} 00^{\prime} 45.84^{\prime \prime} / 46^{\circ} 16^{\prime} 08.38^{\prime \prime}$ & DM & Jul 2002 & SPF 56180 \\
\hline PSA-I & Cibratel, Itanhaém, SP & $24^{\circ} 1 I^{\prime} 26.90^{\prime \prime} / 46^{\circ} 47^{\prime} 33.16^{\prime \prime}$ & $\mathrm{MCO}$ & Aug 1997 & SPF 56186 \\
\hline PSA-RI & Ilha do Cardoso, SP & $25^{\circ} 06^{\prime} 29.49^{\prime \prime} / 47^{\circ} 53^{\prime} 41.20^{\prime \prime}$ & EJP & Aug 1989 & $*$ \\
\hline PSA-A & Ponta da Armação, Florianópolis, SC & $27^{\circ} 44^{\prime} 50.77^{\prime \prime} / 48^{\circ} 29^{\prime} 54.22^{\prime \prime}$ & ECO & Nov 1997 & SPF 56181 \\
\hline PSA-L & Lagoinha, Florianópolis, SC & $27^{\circ} 46^{\prime} 43.79^{\prime \prime} / 48^{\circ} 29^{\prime} 15.84^{\prime \prime}$ & $\mathrm{ECO}$ & Nov 1997 & SPF 56187 \\
\hline
\end{tabular}

SC- Santa Catarina State, SP- São Paulo State. Collectors: DM- Daniela Milstein, EJP - Edison José de Paula, ECO - Eurico Cabral de Oliveira, MCOMariana Cabral de Oliveira. * Conchocelis phase in culture (Laboratório de Algas Marinhas Édison J. de Paula, Instituto de Biociências, USP). ' Data obtained from Oliveira and Ragan [2].

WI). All PCR reactions were performed in a MiniCycler thermocycler (MJ Research, Watertown, MA) and cycles varied according to the region to be amplified: Introns $94^{\circ} \mathrm{C}$ for 4 min, 35 cycles of $94^{\circ} \mathrm{C}$ for $30 \mathrm{sec}, 60^{\circ} \mathrm{C}$ for 1 $\min , 72^{\circ} \mathrm{C}$ for $2 \mathrm{~min}$, and a final extension step at $72^{\circ} \mathrm{C}$ for 7 min. cox $2-3$ region $-94^{\circ} \mathrm{C}$ for 4 min, 5 cycles of $93^{\circ} \mathrm{C}$ for $1 \mathrm{~min}, 45^{\circ} \mathrm{C}$ for $1 \mathrm{~min}, 72^{\circ} \mathrm{C}$ for $1 \mathrm{~min}$, followed by 30 cycles of $93^{\circ} \mathrm{C}$ for $30 \mathrm{sec}, 55^{\circ} \mathrm{C}$ for $30 \mathrm{sec}, 72^{\circ} \mathrm{C}$ for $30 \mathrm{sec}$, and a final extension step at $72^{\circ} \mathrm{C}$ for $5 \mathrm{~min}$. $r b c \mathrm{~L}$ $\mathrm{S}$ region $-94^{\circ} \mathrm{C}$ for $4 \mathrm{~min}, 35$ cycles of $94^{\circ} \mathrm{C}$ for $1 \mathrm{~min}$, $42^{\circ} \mathrm{C}$ for $1 \mathrm{~min}, 72^{\circ} \mathrm{C}$ for $1 \mathrm{~min}$ and $30 \mathrm{sec}$, and a final extension step at $72^{\circ} \mathrm{C}$ for $10 \mathrm{~min}$. Primers used for amplification and sequencing are listed in Table 2. Negative controls for PCR reactions, that included all reagents except DNA template, were performed. At least three independent PCR reactions were pooled together before sequencing [26].

PCR products were purified using the MicroSpin ${ }^{\mathrm{TM}}$ S-300 HR Columns (Amersham Pharmacia Biotech, Piscataway, $\mathrm{NJ}$ ), and were directly sequenced on an ABI PRISM ${ }^{\mathrm{TM}} 310$ Genetic Analyser or 3100 DNA Sequencer (Applied Biosystems, Foster City, CA) using the sequencing kit " BigDye $^{\mathrm{TM}}$ Terminator Cycle Sequencing Ready Reaction" (Applied Biosystems) according to manufacturer's specifications. Sequences were manually assembled and aligned with BioEdit version 5.0.6 [27]. Ambiguous nucleotides within the same individual sequence position were checked against the sequencing chromatograms, to confirm validity of the nucleotide.

\section{Analyses of population structure}

Software DNAsp [28] were used to calculate summary statistics (H), neutrality tests Tajima's $D$ [29] and Fu's Fs [30]. For median joining (MJ) network analyses, sequences previously aligned with Fluxus' DNA Alignment 1.121 software [31] were input in the program NETWORK 4.1 [31].
All parameters implemented in NETWORK were set to default: Characters weights (10 for all characters), transversions/transitions ratios (1:1) and the distance calculation method (connection cost). Parameter epsilon, a weighted genetic distance measure, was set to 0. Population genetics analyses for intron + HEG were carried out using Arlequin [32]. The dataset was input as sequence length polymorphism (based on PCR results) with ten individuals per population. Introns were grouped in four categories according to their size: $1-616$ bp; 2 - from 791 to $792 \mathrm{bp}$; 3- $909 \mathrm{bp}$; 4- from 1054 to $1058 \mathrm{bp}$. This dataset was analyzed for F-statistics implementation. This software was also used for Mantel's test of isolation by distance. PSA-B, PSA-D and PSA-R individuals were excluded from these analyses (data available for only one individual per population).

Intron nomenclature adopted in this work (i.e. S1506) was modified from Johansen and Haugen [33] and the insertion location of the introns is given according to the reference position in Escherichia coli SSU rDNA.

\section{Cloning and in vitro transcription}

Primers $1400 \mathrm{~F}$ and $18 \mathrm{~S} 3$ ' were used for the amplification of the nuclear SSU rDNA intron, including the flanking $213 \mathrm{bp}$ of the SSU rDNA 5'exon and $27 \mathrm{bp}$ of the SSU rDNA 3'exon. Amplicons of one individual of PSA-G, PSA-L, PSA-T and PSA-V populations were cloned according to manufacturer's specifications in pGEM $^{\circledR}-\mathrm{T}$ vectors (Promega Corporation, Madison, WI), and were replicated in E. coli DH10B. Plasmids were recovered and purified with Wizard ${ }^{\circledast}$ plus SV Minipreps DNA Purification System (Promega) according to manufacturer's protocol. Inserts were PCR amplified with primers T7 and 18S3' for an in vitro transcription assay (Table 2), and purified with the kit Wizard ${ }^{\circledast}$ SV Gel and PCR Clean up System 


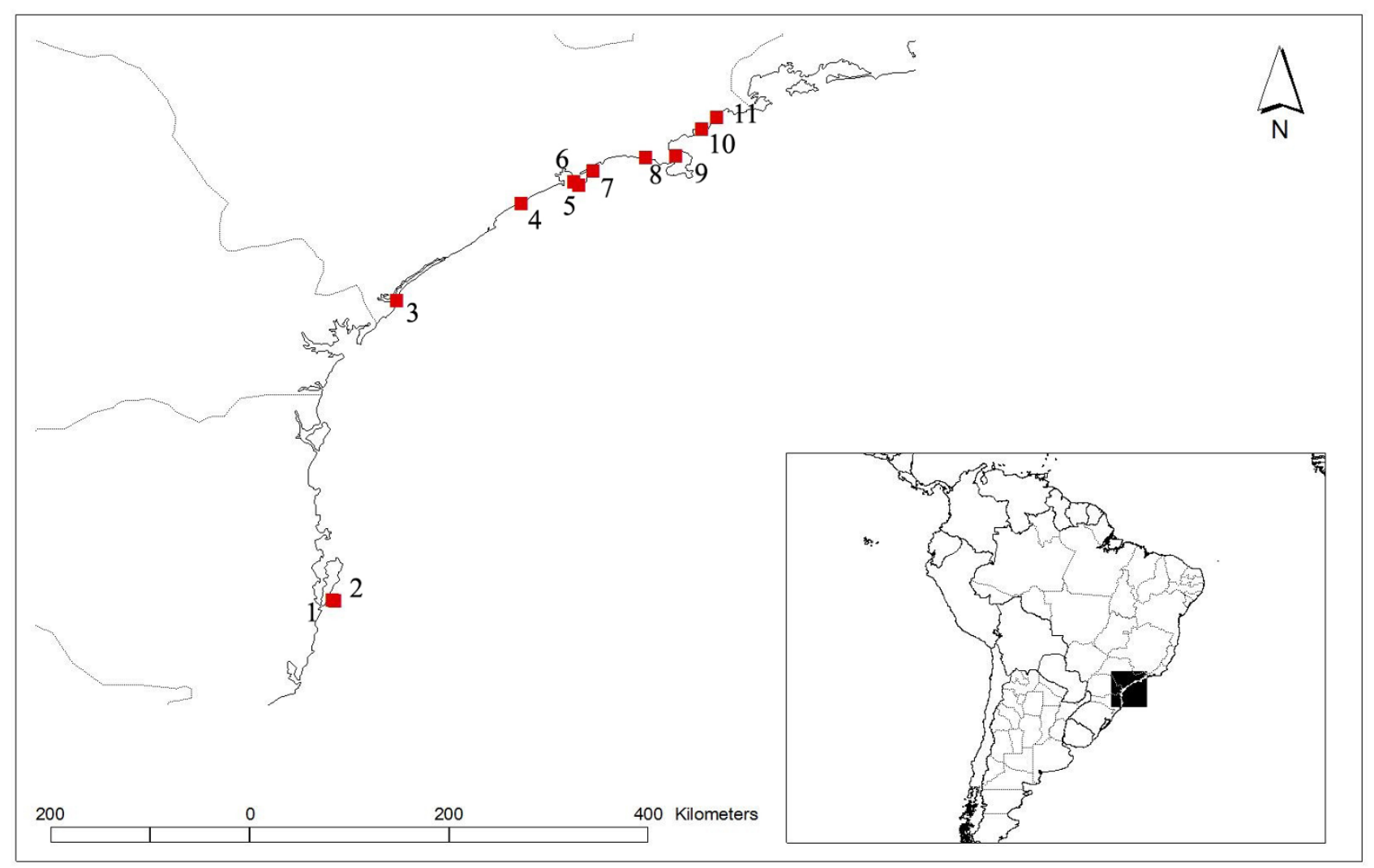

Figure I

Map of South America highlighting Porphyra spiralis var. amplifolia (PSA) collection sites. I- PSA-A; 2- PSA-L; 3PSA-R*; 4- PSA-I; 5- PSA-S; 6- PSA-T; 7- PSA-G; 8- PSA-C; 9- PSA-D*; I0- PSA-B*; II- PSA-V. Additional information on collections sites are presented on Table I. * Data obtained from Oliveira and Ragan [2].

Table 2: Primers used for intron amplification and sequencing.

\begin{tabular}{llll}
\hline Primers & Sequences & Position in PSA & References \\
\hline I400F & 5'-TGTACACACCGCCCGTC-3' & SSU rDNA, 1659 & Oliveira and Ragan [2] \\
iF-I & 5'-ACAAGGTTTCCGAAAGGG-3' & Oliveira and Ragan [2] \\
iR-3 & 5'-TTAATGTCGTGACCGCGCA-3' & Intron, I798 & Oliveira and Ragan [2] \\
iF-2 & 5'-AAGTCGCTTTTGTTGGC-3' & Intron, 2306 & Oliveira and Ragan [2] \\
iR-2 & 5'-TTCGGACTGACTGCGTCG-3' & Intron, 2382 & Oliveira and Ragan [2] \\
iF-3 & 5'-CGCTGGATGGTAATAAGGTG-3' & Intron, 246I & Oliveira and Ragan [2] \\
iR-I & 5'-GACTCTGCTTTCGCAG-3' & Intron, 2580 & Oliveira and Ragan [2] \\
I8S3' & 5'-GATCCTTCTGCAGGTTCACCTACGGAA-3' & Intron, 2730 & Oliveira and Ragan [2] \\
COX 2F & 5'-GTACCWTCTTTDRGRRKDAAATGTGATGC -3' & SSU rDNA, 2860 & Zuccarello et al. [43] \\
COX 3R & 5'- GGATCTACWAGATGRAAWGGATGTC -3' & cox2-3, I & Zuccarello et al. [43] \\
F993 & 5'- GGTACTGTTGTAGGTAAATTWGAAGG -3' & cox2-3, 433 & Freshwater et al. [46] \\
RBCS3'R & 5'- GTTCTTGTGTTAATCTCAC -3' & rbcL - S, I & Freshwater et al. [46] \\
\hline
\end{tabular}


(Promega) according to manufacturer's protocol. Negative controls for PCR reactions were performed.

Transcription reactions $(50 \mu \mathrm{L})$ were performed with $1 \mu \mathrm{g}$ of purified PCR products and T7 RNA polymerase enzyme, in T7 RiboMAX ${ }^{\text {тм }}$ Express large scale RNA production system kit (Promega) according to manufacturer's protocol. Transcription reactions were incubated at $45^{\circ} \mathrm{C}$ for $45 \mathrm{~min}$, then were digested with RQ1 RNase-free DNase (Promega) and RNA transcripts were extracted with phenol ( $\mathrm{pH}$ 4.7): chlorophorm: isoamyl alcohol $(125: 24: 1)$.

\section{Intron in vitro self-splicing assays}

The extracted RNAs were tested for intron qualitative in vitro self-splicing by the following assay: an aliquot of each transcription reaction was incubated at $45^{\circ} \mathrm{C}$ for 45 $\mathrm{min}$, in the presence of the self-splicing buffer as described in Sogin and Edman [34]: $100 \mathrm{mM}\left(\mathrm{NH}_{4}\right)_{2} \mathrm{SO}_{4}, 50 \mathrm{mM}$ Tris-HCl pH 7.5, $60 \mathrm{mM} \mathrm{MgCl}{ }_{2}$ and $0.2 \mathrm{mM}$ GTP. The RNA was extracted with phenol: chlorophorm: isoamyl alcohol $(25: 24: 1)$. To verify if introns self-spliced from RNA, $2 \mu \mathrm{L}$ of RNA were denatured at $70^{\circ} \mathrm{C}$ for $10 \mathrm{~min}$ in $18 \mu \mathrm{L}$ of formamide denaturing buffer (according to manufacturer's protocol) and were visualized in an ethidium bromide stained $2 \%$ agarose gel [35].

Reverse transcription reactions followed by PCR $(50 \mu \mathrm{L})$ were carried out with $1 \mathrm{X}$ AccessQuick ${ }^{\mathrm{TM}}$ Master Mix buffer (Promega), approximately $10 \mathrm{ng}$ RNA, $0.2 \mu \mathrm{M}$ of each primer (1400F and 18S3') and 5 units AMV reverse transcriptase (Promega). For cDNA synthesis, the reactions were incubated at $45^{\circ} \mathrm{C}$ for $45 \mathrm{~min}$ followed by PCR cycle: $95^{\circ} \mathrm{C}$ for $2 \mathrm{~min} ; 40$ cycles at $95^{\circ} \mathrm{C}$ for $30 \mathrm{sec}$ and $60^{\circ} \mathrm{C}$ for $30 \mathrm{sec}$; with a final extension step at $72^{\circ} \mathrm{C}$ for $5 \mathrm{~min}$ according to manufacturer's protocol. All PCR reactions included negative controls and were performed in a MiniCycler thermocycler (MJ Research).

PCR products were purified from agarose gels using Wiz$\operatorname{ard}^{\oplus}$ SV Gel and PCR clean up system kit (Promega) and were re-amplified with primers $1400 \mathrm{~F}$ and $18 \mathrm{~S} 3^{\prime}$ as described above. The PCR cycle used was as described for RT-PCR. PCR products were purified with Wizard ${ }^{\circledast}$ SV Gel and PCR clean up system kit (Promega) and were directly sequenced as described above.

\section{Results \\ Characterization of introns size polymorphisms at different PSA populations}

Group I S1506 introns from 80 Porphyra spiralis var. amplifolia (PSA) collected at eight different sites in the Southern Brazilian shore were PCR amplified. Visualization in $0.7 \%$ agarose gel unveiled four introns size polymorphism among different PSA populations. The smallest introns were amplified from PSA-V population (616 bp) and the largest introns were amplified from PSA-A, PSA-I, PSA-L and PSA-T populations (1054-8 bp; Table 3). Intron size polymorphisms within a population were detected only for PSA-S and PSA-T collections. Presence of two introns of different sizes occurring in the same sample was observed for one individual from PSA-S (792 bp +909 bp) and for one individual from PSA-T (792 bp + 1055 bp). Based on these PCR results, introns from 10 individuals of PSA-S, PSA-T and PSA-V were sequenced, and for the remaining populations, introns from two individuals per population were sequenced. Sequencing data from individuals PSA-B, PSA-D and PSA-R [2] were obtained from the GenBank. In total, 44 introns sequences were analyzed [GenBank accession numbers from FJ147627 to F[147667].

Introns size polymorphisms are due to insertions from 42 to 482 bp in intron P1 paired element. Variability among the 44 PSA sequences (introns and P1-extension) yielded 17 different haplotypes (see additional file 1), with haplotype diversity $(\mathrm{H})$ of 0.895 . P1-extension is the most variable region presenting nucleotide substitutions and indels. When P1-extension was excluded from this comparison, only six different haplotypes were obtained with $\mathrm{H}=0.175$, and the substitutions observed were limited to intron unpaired terminal loops (data not shown). The neutrality tests results for introns without the P1-extension were all negative and significant (Tajima's D = -1.99,

Table 3: Seventeen haplotypes (HI to HI7) distributed over I I Porphyra spiralis var. amplifolia (PSA) populations (Table I).

\begin{tabular}{|c|c|c|c|}
\hline Haplotype/Intron size & PSA Populations & ORF & His-Cys \\
\hline $\mathrm{HI}$ - 1056 bp & PSA-A & 137 aa & Yes, f/s \\
\hline H2 - 1058 bp & PSA-I & 138 aa & Yes \\
\hline H3 - I054 bp & PSA-R ${ }^{1,2}$ & 137 aa & Yes, f/s \\
\hline H4 - I055 bp & PSA-L & 137 aa & Yes \\
\hline H5 - 1055 bp & PSA-I, -L, -T & 137 aa & Yes \\
\hline H6 - 909 bp & PSA-DI & 87 aa & Yes, f/s \\
\hline H7 - 909 bp & PSA-S, -T & 88 aa & Yes, f/s \\
\hline H8 - 79I bp & PSA-C & 49 aa & No \\
\hline H9 - 792 bp & PSA-G & 50 aа & No \\
\hline HIO - 792 bp & PSA-G, -S, -T & 50 aа & No \\
\hline HII - 792 bp & PSA-T & 50 aa & No \\
\hline HI 2 - 792 bp & PSA-S & 50 aa & No \\
\hline HI3 - 79I bp & PSA-S & 50 aa & No \\
\hline HI4 - 744 bp & PSA-BI & 45 aa & No \\
\hline HI5 - 616 bp & PSA-V & 8 aа & No \\
\hline $\mathrm{HI} 6-616 \mathrm{bp}$ & PSA-V & 8 aa & No \\
\hline $\mathrm{HI} 7-616 \mathrm{bp}$ & PSA-V & 8 aа & No \\
\hline
\end{tabular}

Intron sizes in base pairs (bp), homing endonuclease open reading frames (ORF) sizes in amino acids (aa) and if the His-Cys box motif is present are indicated; $\mathrm{f} / \mathrm{s}$ indicates if frame shifts corrections are necessary for establishing the correct $\mathrm{His}-\mathrm{Cys}$ box reading frame. Data obtained from: ' Oliveira and Ragan [2], ${ }^{2}$ Haugen et al [4]. 
$\mathrm{p}<0.05 ; \mathrm{Fu}$ 's $\mathrm{F}=-3.63, \mathrm{p}<0.02)$, suggesting a rapid population expansion.

Complementary strands of P1-extensions of the 17 haplotypes were translated in silico to amino acid sequences according to Haugen et al. [4]. Open reading frames from eight to 150 amino acids, were generated (Table 3, Figure 2) and were blasted against other available proteins in GenBank with BLASTP [36]. Start codons for HEG were found in all ORFs, however when compared to others HEs, premature stop codons or stop codon deletions were observed. His-Cys box motifs, zinc binding sites and active sites were characterized on intron-coding complementary strands for six PSA individuals from three different populations (Haplotypes H2, H4 and H5, Table 3, Figure 2). For the remaining introns, His-Cys box motifs, zinc binding sites and active sites were only verified when frame-shifts corrections were manually inserted in silico, or were absent. These results indicate that P1-extension of the 17 haplotypes are degenerated HEG.

\section{Cox2-3 and rbcL-S analyses}

Cox2-3 region was PCR amplified and sequenced for five individuals of each population analyzed in this work [GenBank accession numbers from FJ147587 to FJ147626]. The amplified region has a total length of 457 bp for all individuals, being the cox2-3 spacer 167 bp long. Variability among the 40 PSA cox2-3 region sequences analyzed, yielded five different haplotypes (Table 4). Haplotypes differed from each other by one or two base-pairs $(0.2 \%$ to $0.7 \%)$, with $H=0.426$. Similar to the results obtained for the intron analyses, the Tajima's D values for cox2-3 were negative $(-1.42)$, but only marginally significant $(0.05<\mathrm{p}<0.10)$.
$R b c L-S$ region was PCR amplified and sequenced for five individuals of populations PSA-S, PSA-T and PSA-V, and for two individuals of the remaining populations. The region amplified is $570 \mathrm{bp}$ long for all individuals, being the $r b c \mathrm{~L}-\mathrm{S}$ spacer 77 bp long. A single haplotype was obtained for all 25 analyzed individuals, with no divergence within and among populations [GenBank accession numbers from FJ147668 to FJ147694].

\section{Genetic relationships and population structure of PSA populations}

To determine the genetic relationships among the studied PSA populations, three median joining networks were constructed. The first one included intron + HEG sequences (Figure $3 \mathrm{~A}$ ), the second was performed with intron without HEG sequence data (Figure 3B), and the third was constructed with cox 2-3 region sequences (Figure $3 \mathrm{C}$ ).

The network generated for intron + HEG sequences shows three main clusters connected by median vectors, which represent missing intermediates, that is extant haplotype that was not sampled or an extinct ancestral haplotype [37]. The first cluster comprises introns with 1054-8 bp represented by haplotypes $\mathrm{H} 1$ to $\mathrm{H} 5$ and introns with 909 bp represented by haplotypes $\mathrm{H} 6$ and $\mathrm{H} 7$. The most common haplotype in this cluster is $\mathrm{H} 5$, which occurs in three geographically distant populations (PSA-L, PSA-I, PSA-T). Haplotypes H2, H4 and H5 present the intact His-Cys box motif whereas haplotypes $\mathrm{H} 1$ and $\mathrm{H} 3$ present His-Cys box only when frame shifts are inserted. Haplotypes H6 and H7 present extensive deletions in the HEG, but still have part of the His-Cys box motif. The second cluster comprises exclusively 791-2 bp introns without His-Cys box

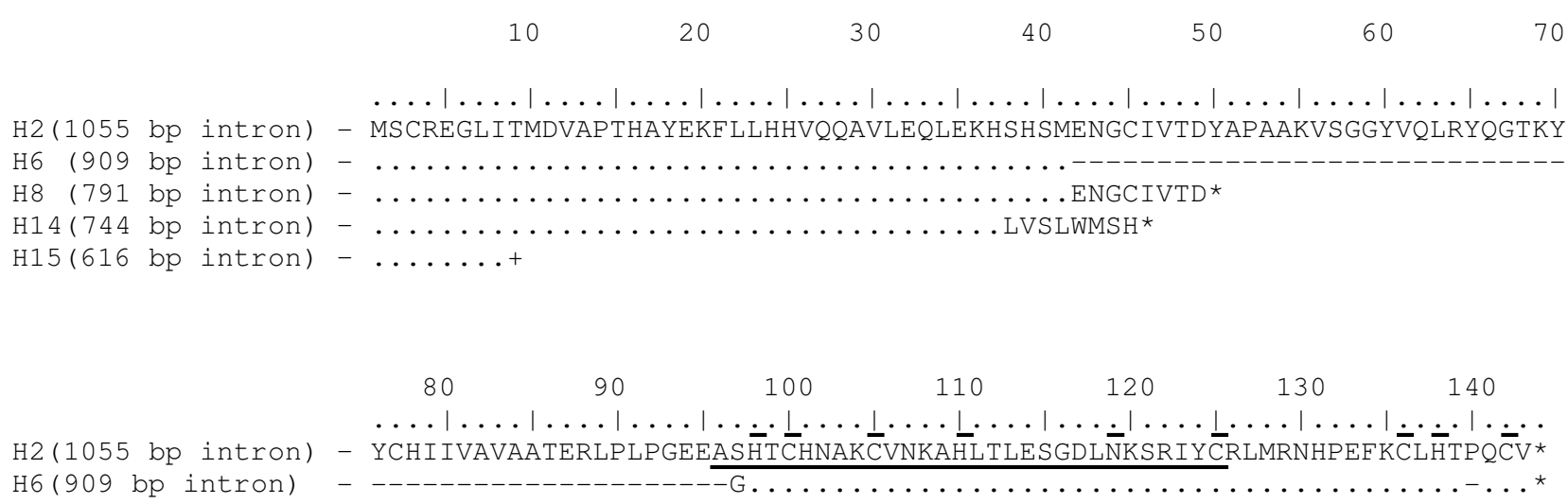

Figure 2

Translation of homing endonuclease gene open reading frames of the five size polymorphisms. The His-Cys box motif is underlined and zinc binding sites and active sites found in I-Ppol endonuclease are indicated by line above amino acids. Stop codon is indicated by asterisk. End of sequence without stop codon is indicated by $+\mathrm{H}-$ haplotype. 
Table 4: Cox2-3 region haplotype frequencies for each population of Porphyra spiralis var. amplifolia (PSA).

\begin{tabular}{llllll}
\hline PSA Population & Hapl A & Hapl B & Hapl C & Hapl D & Hapl E \\
\hline PSA-A & 5 & - & - & - & - \\
PSA-C & 5 & - & - & - & - \\
PSA-G & 5 & - & - & - & - \\
PSA-I & 4 & - & - & - & 1 \\
PSA-L & - & - & 5 & - & - \\
PSA-S & 4 & - & - & 1 & - \\
PSA-T & 5 & - & - & - & - \\
PSA-V & 2 & 3 & - & - & - \\
Total & 30 & 3 & 5 & 1 & 1 \\
\hline
\end{tabular}

motif, represented by haplotypes $\mathrm{H} 8$ to H13. The most common haplotype in this cluster is H10, which is found in populations PSA-G, PSA-S and PSA-T. The third cluster comprises the smaller introns (616 bp and $744 \mathrm{bp}$ ) represented by haplotypes H14 to H17. The most common haplotype in this cluster is $\mathrm{H} 17$, which is from population $P S A-\mathrm{V}$. The intron + HEG network shows a pattern of isolation by distance for PSA populations.

The results for pairwise Fst analyses of frequency of allele size polymorphisms are presented in Table 5. It was possible to note three distinct patterns of significant Fst values, according to population geographic distribution. Populations PSA-A,PSA-I and PSA-L presented significant Fst values when compared to populations $P S A-\mathrm{C}, P S A-\mathrm{G}$, PSA-S and PSA-T, and all of them presented significant Fst values when compared to population PSA-V. Mantel's test results found significant correlation between Fst values and geographic distance $(\mathrm{p}=0.028)$ corroborating the hypothesis of isolation by distance suggested by intron + HEG network.

The minimum spanning tree generated for intron without HEG (Figure 3B) and cox 2-3 region sequences (Figure 3C) exhibit a star-like topology. For intron without HEG, the most frequent central haplotype occurred in 9 out of 11 collection sites (39 of the 44 individuals; $89 \%$ ). For cox23 region sequences, the majority of the individuals ( 7 of the 8 populations accounting for 30 out of 40 individuals analyzed; $75 \%$ ) possess the most frequent central haplotype. According to both networks topologies, a recent population expansion was detected for these markers.

\section{Self splicing assays}

Introns and exons flanking regions of one individual from populations PSA-V (616 bp), PSA-G (792 bp), PSA-T (909 bp) and PSA-L (1055 bp) were cloned for in vitro transcription. Pre-RNA of the four individuals were incubated at $45^{\circ} \mathrm{C}$ for $45 \mathrm{~min}$ to verify the self-splicing reaction. The self-splicing reaction was observed, however just a part of the introns was spliced, while the other part remained attached to exons (as pre-RNA, additional file 2).

To confirm whether the exons were ligated, a RT-PCR reaction was performed with primers $1400 \mathrm{~F}$ and $18 \mathrm{~S} 3$ ' using the RNA previously incubated in the conditions described above. The bands were excised from the gel and re-amplified with primers $1400 \mathrm{~F}$ and $18 \mathrm{~S} 3$ ' which anchors in the exons. The results of the re-amplification are shown in additional file 3. Amplicons were sequenced and the smaller bands were the joined 5' and 3' exons, presenting the reconstructed insertion site.

\section{Discussion \\ Characterization of introns size polymorphisms at different PSA populations}

Group I introns are well documented in the literature occurring in the red algal genera Bangia and Porphyra (Order Bangiales) [5,13-15]. Some of these group I introns present ORFs of different sizes inserted in their P1 and P2 paired elements [3-5]. Size variation in these ORFs represents different stages of the HEG cycle (full length, degenerated or absent). Goddard and Burt [38] postulated that the HE coded by an intron recognizes the intron insertion site in an intronless population, invade it by lateral transfer and then it is vertically transmitted to the offspring. After being fixed with high frequencies in a population, the HEG degenerates to a non-functional state, and then the intron and the HEG tend to be lost. In this way, the intron recognition site is reestablished becoming available to be invaded again by an active HEGcontaining intron from the same species or from a closely related species, thus restarting the homing cycle.

In a previous work, Oliveira and Ragan [2] characterized three size polymorphisms for group I introns from three PSA individuals. In this work, two more sizes were characterized, in a total of five different sizes distributed in 11 PSA populations along the Brazilian coast. According to the cycle proposed by Goddard and Burt [38], HEGs can be found in three different character states: functional (full length), nonfunctional (degenerated) and absent (both HEG and intron). In PSA populations analyzed in this work, we could only detect the nonfunctional state represented by HEG degeneration, indicating that full length HEG containing intron was once fixed for these populations. The different states of the intron + HEG are not always found within natural populations, probably as a result of insufficient sampling [1].

Müller et al. [5] evaluated if the cycle proposed by Goddard and Burt [38], applied to group I introns present in the order Bangiales. Presence of introns containing degenerated HEGs, presence of introns without HEG and absence of introns, all these states scattered along individ- 

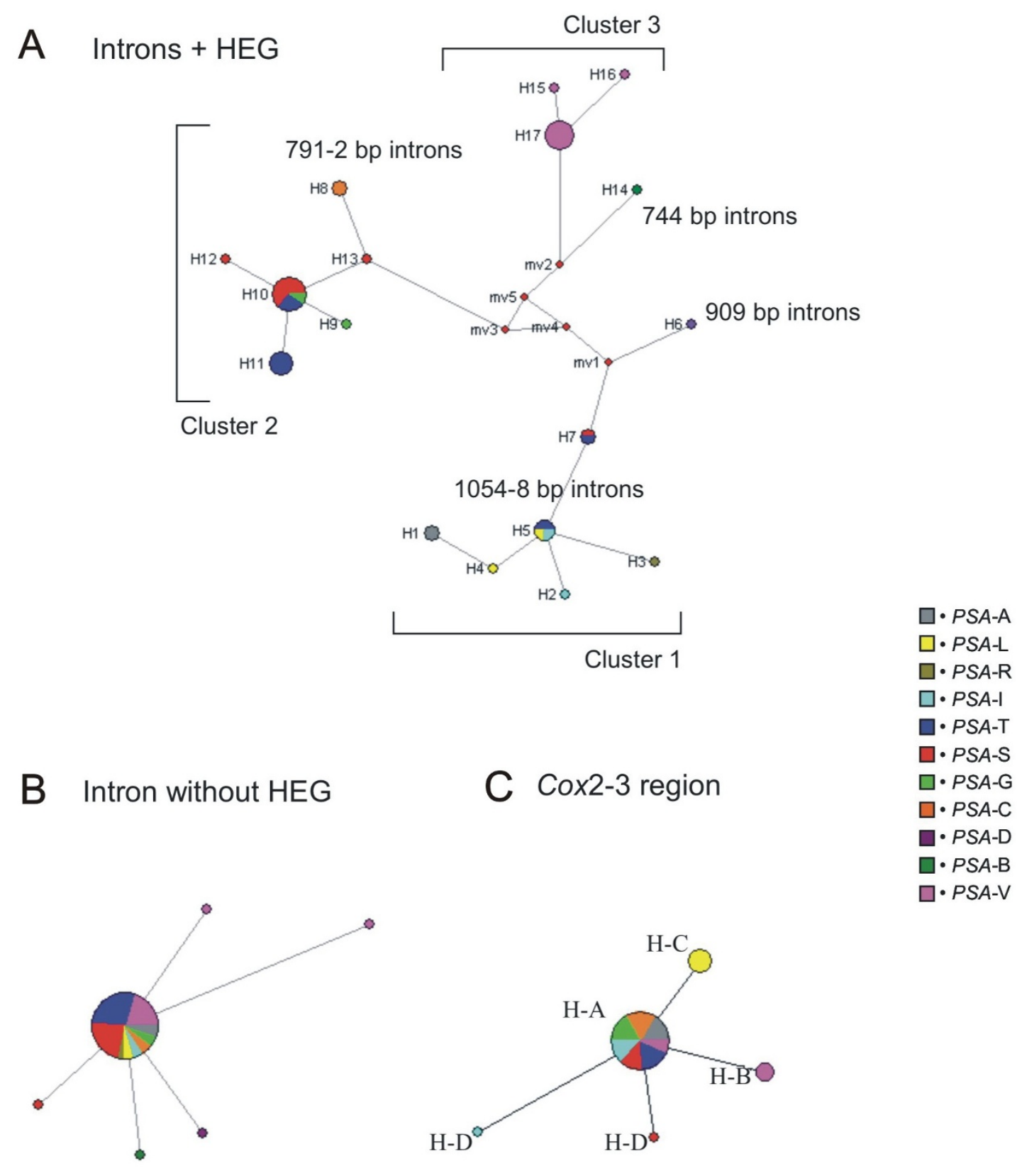

Figure 3

Median-joining networks: A - Introns + homing endonuclease gene (HEG); B - and introns without HEG; C Cox2-3 region. Circles indicate sequence types and circle sizes are proportional to haplotype frequency. Lines indicate substitutions (not on scale). MV- median vector, $\mathrm{H}$ - haplotype. Haplotypes were not plotted on intron without HEG network.

uals from different species, indicated that Goddard \& Burt [38] model is supported by intron + HEG distribution in the order Bangiales.
Of the 44 introns sequences, only six presented the intact His-Cys box motif. Although these ORFs did not present frameshifts mutation, they terminated prematurely relatively to the amino acid sequence for the homing endonuclease I-PpoI from the slime mould Physarum polycephalum 
Table 5: Population Pairwise Fst.

\begin{tabular}{|c|c|c|c|c|c|c|c|c|}
\hline Population & PSA-A & PSA-C & PSA-G & PSA-I & PSA-L & PSA-S & PSA-T & PSA-V \\
\hline PSA-A & & + & + & - & - & + & + & + \\
\hline PSA-C & 1.0000 & & - & + & + & - & - & + \\
\hline PSA-G & 1.0000 & 0.0000 & & + & + & - & - & + \\
\hline PSA-I & 0.0000 & 1.0000 & 1.0000 & & - & + & + & + \\
\hline PSA-L & 0.0000 & 1.0000 & 1.0000 & 0.0000 & & + & + & + \\
\hline PSA-S & 0.9000 & 0.000 & 0.000 & 0.9000 & 0.9000 & & - & + \\
\hline PSA-T & 0.6996 & 0.1205 & 0.1205 & 0.6996 & 0.6996 & -0.004 & & + \\
\hline PSA-V & 1.0000 & 1.0000 & 1.0000 & 1.0000 & 1.0000 & 0.9000 & 0.7537 & \\
\hline
\end{tabular}

Pairwise Fst values of intron size polymorphisms of Porphyra spiralis var. amplifolia populations (PSA, lower left). Significant values are represented by the plus sign, and no significant values are represented by the minus sign (upper right).

[39], likewise Porphyra fucicola and P. umbilicalis HEG sequences [5]. As these sequences were not tested for endonuclease activity, they will be considered as HEG pseudogenes, as suggested by Müller et al. [5].

\section{Cox 2-3 and rbcL-S regions analyses}

Cox 2-3 and $r b c \mathrm{~L}-\mathrm{S}$ regions were sequenced in addition to the SSU rDNA introns, to infer genealogical relationships of PSA populations. Divergence among cox 2-3 haplotypes of the 40 PSA individuals sequenced ranged from $0.2 \%$ to $0.7 \%$. These values are in accordance to the divergence found among cox2-3 haplotypes from Grateloupia doryphora $(0.3 \%$ to $0.6 \%)$ from North Atlantic and North Pacific [19]. However, they differ significantly when compared to the divergence among cox2-3 region from Batrachospermum helminthosum individuals from North America, 0.3\% to $6.5 \%$ [22] and from Acanthophora spicifera individuals from the Hawaiian Islands, where a single haplotype was observed [40].

$R b c$ L-S region has been employed in Rhodophyta as a marker at the inter-specific, intra-specific and intra-population levels $[21,23,41-43]$, with levels of divergence of: $13 \%$ to $18 \%$ for Gracilaria species [41] and $12.5 \%$ to $13.4 \%$ for individuals of the Gymnogongrus complex [42]. However, a unique haplotype from all the sampled range (ca. $800 \mathrm{~km}$ ) was determined for the $r b c \mathrm{~L}-\mathrm{S}$ sequences from 25 PSA individuals.

\section{Population structure and genetic relationships of PSA populations}

Genetic relationships of the 17 haplotypes (introns + HEG) obtained from PSA populations were accessed through network analyses. The network exhibit three main clusters suggesting a pattern of isolation by distance for the populations analyzed. The same grouping pattern was obtained for Fst analysis. Mantel's test corroborated the hypothesis indicated by the two previous analyses. Therefore, isolation by distance appears to be the basic process accounting for structure in PSA populations, manifested in a cline of HEG degeneration. Populations sam- pled at the southernmost end of the distribution present the entire His-Cys box motif, while the population sampled at the northernmost end of the distribution, considering the start codon proposed by Haugen et al. [4], has only eight amino acids of the HE. Distributed between these two extremes, are the intermediate-sized alleles.

The neutrality tests results for the intron without HEG indicated a fast population growth from an ancestor population with small effective number. At the same time, cox 2-3 region results were marginally significant for the neutrality tests and $r b c \mathrm{~L}-\mathrm{S}$ region results showed no nucleotide variability. The low variability in these markers, also observed in the networks, is consistent with a demographic event of expansion from a population with low effective number affecting all loci. These results are not compatible to the HEG length polymorphism. The intron + HEG marker showed remarkable variation in length in the same individuals that presented few variations for the other markers. Therefore, in the same window of time, much more variation was accumulated in HEG than in sequence variation in the other three markers, which are probably under different selection constraints. Considering the recent population expansion for PSA along the Brazilian coast, degeneration of HEG was a very fast process. First, if we assume that a functional HEG have a cost to the host cell, then natural selection will increase the frequency of nonfunctional elements; and second, if we assume that the HEG was already fixed for PSA populations (there is no availability of insertion site), then the frequency of nonfunctional elements will increase due to low selection to keep a functional HEG [38].

Based on these assumptions, two different scenarios can be proposed to explain intron + HEG evolution in PSA populations: In the first scenario, the horizontal transfer of intron + HEG occurred in an ancestral individual, prior to the colonization of PSA populations in the Brazilian coast. Therefore, it is reasonable to believe that the same bottleneck event that was detected by the three markers (intron without HEG, cox2-3 and $r b c \mathrm{~L}-\mathrm{S}$ regions) probably 
had as a consequence the fixation in the population of the full length HEG (functional). If the largest introns are considered as the ancestral state, then the oldest populations are located in the southernmost end of the distribution, and as long as individuals migrate to the north, their HEGs tend to degenerate. This scenario is consistent with the proposed hypothesis for intron insertion and evolution in the order Bangiales based on phylogenetics analysis of SSU rDNA and respective group I introns - Intron horizontal transfer to an ancestor of the order Bangiales, followed by vertical inheritance and evolution within the order as proposed by Muller et al [5].

In the second scenario, the ancestral PSA individual lack intron + HEG. It is possible to suggest that the horizontal transfer of intron + HEG in PSA SSU rDNA occurred after the event of demographic expansion. In this case, the intron with the most degenerated HEG - with more deletions accumulated - is present in the oldest population. This state was found in the northernmost population, suggesting a horizontal transfer event to have occurred in an individual from the PSA-V population. After the horizontal transfer event, the functional HEG invaded the other PSA populations by gene flow, being the largest HEG present in the more recently invaded populations, at the southernmost end of distribution. Within the context of intron evolution in the order Bangiales, this scenario is possible assuming the hypothesis that more than one intron insertion events has occurred during the divergence of the order [5].

This is the first report addressing intron evolution focusing on only one species. Understanding the mechanisms beyond intron + HEG evolution has been a challenge, despite all the knowledge obtained for these elements.

\section{Self splicing assays}

As self-splicing catalytic properties of group I introns are highly dependent on intron three-dimensional structure [44], we verified whether the occurrence of insertions in P1 paired element alters intron catalytic activities, checking if introns sizes variants self-splice in vitro. One way to check for intron excision is the confirmation of exons ligation [45].

The four intron size variants analyzed in this work selfspliced in vitro. Therefore, the occurrence of different size polymorphisms in intron P1 paired element do not refrain intron self-splicing mechanism, although there is a hypothesis that the presence of HEG may diminish selfsplicing efficiency [1]. The loops are strategic localities for HEG insertion. HEG have been considered invasive mobile elements that remain neutral to the host when inserted into introns, becoming invisible to negative selection [6]. If group I introns lose their self-splicing capabil- ity due to the presence of a HEG, they both would probably be eliminated from the gene they were inserted, since there is a strong selection against non-functional rDNA genes.

\section{Conclusion}

Commercial exploitation, mariculture and introduction of invasive species have been a major problem in the assignment of Porphyra geographic origins. Phenotypic plasticity along with a simple morphology is also an obstacle in Porphyra identification. Furthermore, scientific researches are more focused on taxonomy and phylogeny of the group than in population surveys. Population structure of Porphyra spiralis var. amplifolia could be assigned by HEG degeneration, although not by cox2-3 and $r b c \mathrm{~L}-\mathrm{S}$ regions. Therefore, intron size polymorphism is a suitable population marker for this species, and it can be rapidly detected using PCR assay.

The intron size polymorphism found in the PSA populations, corroborate the HEG cycle proposed by Goddard \& Burt [38], indicating that the degenerated HEGs are reminiscent of the presence of a full-length and functional HEG, once fixed for PSA populations. The cline of HEG degeneration detected for PSA populations along the Southern Brazilian coast, determined the pattern of isolation by distance. Analyses with the other markers indicated a demographic event of expansion for PSA, from a population with low effective number. The maintenance of the HEG apparently does not refrain the ability of the intron to self-splice even when the different degrees of degeneration of these elements are present.

\section{Authors' contributions}

DM carried out the research, carried out and interpreted the analyses and wrote the manuscript. MCO conceived the project, interpreted the analysis, supervised the project and revised the manuscript. FMM carried out and interpreted the population genetics analyses and wrote the manuscript. SRM co-supervised of the project and revised the manuscript. All authors participated in the discussions and approved the final manuscript. 


\section{Additional material}

\section{Additional file 1}

Alignment of the haplotypes (H1 to H17, Table 3) of Porphyra spiralis var. amplifolia intron sequences. Exons nucleotides are represented in lowercase letters, and intron and homing endonuclease gene nucleotides are represented in uppercase letters. Homing endonuclease open reading frame (ORF) start (484) and stop (28) positions are shadowed in gray. The orientation of the ORF is indicated by a horizontal arrow. Conserved nucleotides that forms the $u^{*} G$ pair are in positions 6 and 496, respectively. Line above sequences indicates Hys-Cys Box motif. Dashes in the alignment represent gaps.

Click here for file

[http://www.biomedcentral.com/content/supplementary/14712148-8-308-S1.pdf]

\section{Additional file 2}

In vitro self-splicing reaction visualized in $0.7 \%$ agarose gel. Lane 1 , RNA ladder (Invitrogen); lane 2, Porphyra spiralis var. amplifolia (PSA)-V3; lane 3,PSA-G4; lane 4, PSA-T10; lane 5, PSA-L8. Expected sizes for each step of intron self-splicing are given in the right side of the figure. The largest bands are the product of intron cyclization [47]. Click here for file

[http://www.biomedcentral.com/content/supplementary/14712148-8-308-S2.jpeg]

\section{Additional file 3}

Amplification of the cDNA confirming the ligation of the exons. Lane 1, $100 \mathrm{bp}$ DNA ladder (Promega); lanes 2 and 3,Porphyra spiralis var. amplifolia (PSA)-V3; lanes 4 and 5,PSA-G4; lanes 6 and 7, PSA-T10; lanes 8 and 9, PSA-L8.

Click here for file

[http://www.biomedcentral.com/content/supplementary/14712148-8-308-S3.jpeg]

\section{Acknowledgements}

Funds for this project were supported by FAPESP and CNPq (Brazil). We thank Mutue T. Fujii, Nair S. Yokoya and Silvia P. Guimarães (Instituto de Botânica, Projeto Flora Ficológica do Estado de São Paulo) for help during specimen collections; Peik Haugen for helping with suggestions for the manuscript; for the helpful comments of the reviewers and Silvia R. Blanco and Rosario Petti for technical assistance.

\section{References}

I. Haugen P, Simon DM, Bhattacharya D: The natural history of group I introns. Trends Genet 2005, 2 I (2): I I I- I| 9.

2. Oliveira MC, Ragan MA: Variant forms of a group $\mathbf{I}$ intron in nuclear small-subunit rRNA genes of the marine red alga Porphyra spiralis var. amplifolia. Mol Biol Evol I 994, I I: 1 95-207.

3. Vader A, Naess J, Haugli K, Haugli F, Johansen S: Nucleolar introns from Physarum flavicomum contain insertion elements that may explain how mobile group-I introns gained their open reading frames. Nucleic Acids Res 1994, 22:4553-4559.

4. Haugen P, Huss VAR, Nielsen $H$, Johansen $S$ : Complex group-I introns in nuclear SSU rDNA of red and green algae: evidence of homing-endonuclease pseudogenes in the Bangiophyceae. Curr Genet 1999, 36:345-353.

5. Müller KM, Cannone JJ, Gutell RR, Sheath RG: A Structural and Phylogenetic Analysis of the Group ICI Introns in the Order Bangiales (Rhodophyta). Mol Biol Evol 200I, 18:1654-1667.

6. Belfort $M$, Roberts RJ: Homing endonucleases: keeping the house in order. Nucleic Acids Res 1997, 25:3379-3388.
7. Belfort M, Perlman PS: Mechanisms of intron mobility. J Biol Chem 1995, 270(5 I):30237-30240.

8. Chevalier BS, Stoddard L: Homing endonucleases: structural and functional insight into the catalysts of intron/intein mobility. Nucleic Acids Res 200I, 29:3757-3774.

9. Zhao L, Bonocora RP, Shub DA, Stoddard BL: The restriction fold turns to the dark side: a bacterial homing endonuclease with a PD-(D/E)-XK motif. EMBO J 2007, 26:2432-2442.

10. Johansen S, Embley TM, Willassen NP: A family of nuclear homing endonucleases. Nucleic Acids Res 1993, 21 ( I 8):4405.

II. Ragan MA, Bird CJ, Rice EL, Singh RK: The nuclear 185 ribosomal RNA gene of the red alga Hildenbrandia rubra contains a group I intron. Nucleic Acids Res 1993, 2 I (16):3898.

12. Sherwood AR, Sheath RG: Biogeography and systematics of Hildenbrandia (Rhodophyta, Hildenbrandiales) in North America: inferences from morphometrics and rbcL and $18 \mathrm{~S}$ rRNA gene sequence analyses. Eur J Phycol 1999, 34:523-532.

13. Milstein D, Oliveira MC: Molecular phylogeny of Bangiales (Rhodophyta) based on small subunit rDNA sequencing: Emphasis on Brazilian Porphyra species. Phycologia 2005, 44(2):2I 2-22।.

14. Oliveira MC, Kurniawan J, Bird CJ, Rice EL, Murphy CA, Singh RK, Gutell RR, Ragan MA: A preliminary investigation of the order Bangiales (Bangiophycidae, Rhdophyta) based on sequences of the nuclear small-subunit ribossomal RNA genes. Phycol Res 1995, 43:7।-79.

15. Broom JE, Nelson WA, Yarish C, Jones WA, Aguilar Rosas R, Aguilar Rosas LE: A reassessment of the taxonomic status of Porphyra suborbiculata, Porphyra carolinensis and Porphyra lilliputiana (Bangiales, Rhodophyta) based on molecular and morphological data. Eur J Phycol 2002, 37:227-235.

16. Kunimoto M, Kito H, Kaminishi Y, Mizukami Y, Murase N: Molecular divergence of the SSU rRNA gene and internal transcribed spacer I in Porphyra yezoensis (Rhodophyta). J Appl Phycol I999, II:2II-2I6.

17. Kunimoto M, Kito H, Mizukami Y, Murase N, Levine I: Molecular features of a defined genetic marker for the determination of the Porphyra tenera lineage. J Appl Phycol 2003, 15:337-343.

18. Vis ML, Sheath RG: A molecular and morphological investigation of the relationship between Batrachospermum spermatoinvolucrum and B. gelatinosum (Batrachospermales, Rhodophyta). Eur J Phycol 1998, 33:231-239.

19. Marston M, Bohnsack MV: Genetic variability and potential sources of Grateloupia doryphora (Halymeniaceae, Rhodophyta), an invasive species in Rhode Island waters (USA). J Phycol 2002, 38:649-658.

20. Zuccarello GC, West JA: Hybridization studies in Bostrychia. 2: Correlation of crossing data and plastid DNA sequence data within B. radicans and B. moritziana (Rhodophyta, Ceramiales). Phycologia 1997, 36:293-304.

21. Zuccarello GC, West JA: Phylogeography of the Bostrychia calliptera-B. pinnata complex (Rhodomelacea, Rhodophyta) and divergence rates based on nuclear, mitochondrial and plastid DNA markers. Phycologia 2002, 4 I(I):49-60.

22. Chiasson WB, Machesky NJ, Vis ML: Phylogeography of a freshwater red algae Batrachospermum helminthosum in North America. Phycologia 2003, 42(6):654-660.

23. Cohen S, Faugeron S, Martinez EA, Correa JA, Viard F, Destombe C, Valero M: Molecular identification of two sibling species under the name Gracilaria chilensis (Rhodophyta, Gracilariales). J Phycol 2004, 40:742-747.

24. Oliveira EC, Coll J: The genus Porphyra C. Ag. (RhodophytaBangiales) in the American South Atlantic. I. Brazilian species. Bot Mar 1975, 18:191-197.

25. Hibbett DS: Phylogenetic evidence for horizontal transmission of group $I$ introns in the nuclear ribosomal DNA of mushroom-forming fungi. Mol Biol Evol 1996, I3:903-917.

26. Baldwin BG, Sanderson MJ, Porter JM, Wojciechowski MF, Campbell CS, Donoghue MJ: The ITS region of nuclear ribosomal DNA: a valuable source of evidence on angiosperm phylogeny. Ann Missouri Bot Gard 1995, 82:247-277.

27. Hall TA: BioEdit: A user-friendly biological sequence alignment editor and analysis program for Windows 95/98/NT. Nucleic Acids Symp Ser 1999, 41:95-98. 
28. Rozas J, Sanchez-Delbarrio JC, Messeguer X, Rozas R: DNAsp, DNA polymorphism analyses using the coalescent and other methods. Bioinformatics 2003, I9:2496-2497.

29. Tajima F: Statistical method for testing the neutral mutation hypothesis by DNA polymorphism. Genetics 1989, I 23(3):585-595.

30. Fu YX: Statistical tests of neutrality of mutations against population growth, hitchhiking and background selection. Genetics 1997, 147:915-925.

31. Fluxus-engineering.com [http://www.fluxus-engineering.com]

32. Excoffier L, Laval G, Schneider S: Arlequin (version 3.0): an integrated software package for population genetics data analysis. Evolutionary Bioinformatics Online 2005, I:47-50.

33. Johansen S, Haugen P: A new nomenclature of group I introns in ribosomal DNA. RNA 200I, 7:935-936.

34. Sogin ML, Edman JC: A self-splicing intron in the small subunit rRNA gene of Pneumocystis carinii. Nucleic Acids Res 1989, I 7:5349-59.

35. Sambrook J, Fritsch EF, Maniatis T: Molecular Cloning: A Laboratory Manual Cold Spring Harbour Laboratories press; 1989.

36. Altschul SF, Gish W, Miller W, Myers EW, Lipman DJ: Basic local alignment search tool. J Mol Biol 2 I 5:403-4I0.

37. Posada D, Crandall KA: Intraspecific gene genealogies: trees grafting into networks. Trends Ecol Evol 200I, I 6(I):37-45.

38. Goddard MR, Burt A: Recurrent invasion and extinction of a selfish gene. Proc Natl Acad Sci USA 1999, 96:13880-I 3885.

39. Flick KE, Jurica MS, Monnat RJ, Stoddard BL: DNA binding and cleavage by the nuclear intron-encoded homing endonuclease I-Ppo I. Nature 1998, 394:96-I0I.

40. O' Doherty DC, Sherwood AR: Genetic populations structure of the Hawaiian alien invasive seaweed Acanthophora spicifera (Rhodophyta) as revealed by DNA sequencing and ISSR analyses. Pac Science 2007, 6 I (2):223-233.

4I. Destombe C, Douglas SE: Rubisco spacer sequence divergence in the rhodophyte alga: a technique for discrimination of closely related species. Curr Genet 1991, 19:395-8.

42. Maggs CA, Douglas SE, Fenety J, Bird CJ: A molecular and morphological analysis of the Gymnogongrus devoniensis (Rhodophyta) complex in the North Atlantic. J Phycol 1992, 28:2। 4-232.

43. Zuccarello GC, Burger G, West JA, King RJ: A mitochondrial marker for red algal intraspecific relationships. Mol Ecol 1999, 8: $1443-\mid 447$.

44. Golden BL, Gooding AR, Podell ER, Cech TR: A preorganized active site in the crystal structure of the Tetrahymena ribozyme. Science 1998, 282:259-264.

45. Cech TR: Self-splicing of group I introns. Annu Rev Biochem I990, 59:543-568.

46. Freshwater DW, Fredericq S, Butler BS, Hommersand $\mathrm{MH}$, Chase MW: A gene phylogeny of the red algae (Rhodophyta) based on plastid rbc L. Proc Natl Acad Sci USA 1994, 91:728I-7285.

47. Zaug AJ, Grabowski PJ, Cech TR: Autocatalytic cyclization of an excised intervening sequence RNA is a cleavage-ligation reaction. Nature 1983, 301:578-83.
Publish with Bio Med Central and every scientist can read your work free of charge

"BioMed Central will be the most significant development for disseminating the results of biomedical research in our lifetime. "

Sir Paul Nurse, Cancer Research UK

Your research papers will be:

- available free of charge to the entire biomedical community

- peer reviewed and published immediately upon acceptance

- cited in PubMed and archived on PubMed Central

- yours - you keep the copyright
BioMedcentral 